\title{
EXPLAINING THE WATER-HOLDING CAPACITY OF BIOCHAR BY SCANNING ELECTRON MICROSCOPE IMAGES ${ }^{1}$
}

\author{
RUBENS SONSOL GONDIM ${ }^{2 *}$, CELLI RODRIGUES MUNIZ², CARLOS EDUARDO PACHECO LIMA ${ }^{3}$, CARLOS \\ LEVI ANASTÁCIO DOS SANTOS ${ }^{4}$
}

\begin{abstract}
Biochar is a solid material formed during biomass thermochemical decomposition processes. This organic compound has particular properties that may cause effects on soils depending on its feedstock and processing conditions. Thus, the characteristics and purpose of use of this material must be recognized prior to its use. Two types of biochar, derived from different wood sources, were compared, one from caatinga biome species and another from cashew trees. Two species from caatinga biome were used, jurema-preta (Mimosa tenuiflora Willd. Poir.), and marmeleiro (Croton sonderianus Müll. Arg.). This study aimed to identify the best biochar material regionally available to increase water-holding capacity in the soil, based on laboratory tests and microstructural porosity evaluation. Biochar from Caatinga wood demonstrated an improved waterholding capacity if compared to cashew wood biochar. The particle diameters of 2 and $4 \mathrm{~mm}$ showed the highest levels, which were $2,268 \mathrm{~g} . \mathrm{g}^{-1}$ for caatinga wood and $0.574 \mathrm{~g}_{\mathrm{g}} \mathrm{g}^{-1}$ for cashew wood biochars, respectively. While the smaller quantities of macropores and a larger number of micropores (smaller radius) could explain the higher water-holding capacity for biochar from caatinga wood, the thick lignified cell walls of biochar from cashew wood support the idea of a hydrophobic effect contributing to water lower holding capacity.
\end{abstract}

Keywords: Adaptation strategy. Climate change. Irrigation.

\section{CAPACIDADES DE RETENÇÃO HÍDRICA DO BIOCHAR EXPLICADA POR MICROSCOPIA ELECTRÔNICA}

RESUMO - Biocarvão é o material sólido formado durante a decomposição termoquímica da biomassa. Suas propriedades e efeitos no solo variam amplamente com o material de origem e condições de precessamento. Desta forma, é reconhecida a importância de sua caracterização e desempenho para o que se propõe, antes do uso. Foram comparados dois tipos de biochar, de acordo com o material de origem, espécies do bioma Caatinga, Jurema-Preta (Mimosa tenuiflora (Willd.) Poir. associada com Marmeleiro (Croton sonderianus Müll.) Arg. e lenha de cajueiro (Annacardium occidentale L.). O objetivo deste estudo foi identificar biocarvão com melhor desempenho de promover o aumento da capacidade de retenção de água no solo, com base em evidências de laboratório e avaliação de porosidade microestructural. O biocarvão oriundo das espécies da Caatinga demonstrou maior capacidade de retenção de água quando comparado com o biocarvão de lenha de cajueiro, para todos os diâmetros avaliados. Com relação ao tamanho de partículas, níveis maiores de retenção de água foram observados aos $2 \mathrm{~mm}$ e $4 \mathrm{~mm}, 2,268 \mathrm{~g} \mathrm{~g}^{-1}$ para o biocarvão de madeira das espécies da Caatinga e $0,574 \mathrm{~g} \mathrm{~g}^{-1}$ para o biocarvão de madeira de cajueiro, respectivamente. Menores quantidades de macroporos e maior número de microporos (raio menor) foram observados no biocarvão de madeira das espécies da Caatinga, provavelmente relacionado à mais alta capacidade de retenção de água, enquanto densamente lignificadas, as paredes celulares de madeira de cajueiro, sustenta a ideia de que um efeito hidrofóbico pode contribuir para sua menor capacidade de retenção hídrica.

Palavras-chave: Estratégia de adaptação. Mudanças climáticas. Irrigação.

\footnotetext{
${ }^{*}$ Corresponding author

${ }^{1}$ Received for publication in 03/28/2017; accepted in 04/19/2018.

${ }^{2}$ Embrapa Agroindústria Tropical, Fortaleza, CE, Brazil; rubens.gondim@embrapa.br - ORCID: 0000-0001-7887-1832, celli.muniz@embrapa.br - ORCID: 0000-0003-3977-8533.

${ }^{3}$ Embrapa Hortaliças, Brasília-DF, Brasil; carlos.pacheco-lima@embrapa.br- ORCID: 0000-0002-6975-8560.

${ }^{4}$ Department of Soil Science, Universidade Federal do Ceará, Fortaleza, CE, Brazil; carloslevi@hotmail.com - ORCID: 0000-0002-21871804 .
} 


\section{INTRODUCTION}

Carbonized material produced by incomplete burning has proved to keep high levels of organic matter in the Amazon Anthropogenic soils, the socalled Terra Preta do Índio inherited from the preColombian Indian populations (GLASER; LEHMANN; ZECH, , 2002). These authors have also demonstrated that changes in soil physical properties such as in water holding capacity and particle aggregation along with respective effects may increase water availability to crops and reduce erosion risks. Moreover, a reduction in soil density, due to increases in total porosity and water infiltration, helps to reduce nutrient loss through leaching, thus avoiding groundwater table contamination. The same authors also reported that biochar undergoes slow mineralization in the soil, which leads to carbon sinks and greenhouse gas emission reductions, promoting thus carbon sequestration in the soil. Recently, 'slash and char' systems have been seen as an upcoming alternative to the traditional 'slash and burn' agriculture.

Biochar is a solid material formed by thermochemical decomposition of biomass (CHA et al., 2016), and can also be defined as organic matter heated under limited oxygen conditions. Its use in farmland has been proposed to improve fertility and mitigate climate change effects as it increases carbon sequestration, reduces greenhouse gas emissions (nitrous oxide and methane), and improves waterholding capacity in the soil (KARHU et al., 2011).

In this context, Kammann et al. (2011) reported increases in water use efficiency (WUE) of sandy soils when using biochar, as a result of an increase in water-holding capacity and crop tolerance to drought. Likewise, Karhu et al. (2011) showed improvements in water-holding capacity (WHC) of silt loam soil added with biochar and warned of the need to test other types of soil. Novotny et al. (2015) described increases in water retention capacity of soils treated with biochar of different sources. For Laghari et al. (2016), this material can improve the WHC of sandy soils owing to its porous structure, but the rate of application is of utmost importance.

The original structure of wood sources is imprinted on biochar products, so it has an influence on its final physical and structural characteristics. The mineral and carbon skeleton formed retains the rudimentary porosity of the original material (DOWNIE; CROSKY; MUNROE, 2009). Its surfaces may exhibit either hydrophilic or hydrophobic properties. Small pores attract and retain soil water by capillarity for much longer than larger pores (larger than $10 \mu \mathrm{m}$ to $20 \mu \mathrm{m}$ ). The high porosity of biochar is accompanied by high surface areas, to which both hydrophobic and hydrophilic molecules can sorb depending upon its functional chemical groups. In freshly made biochars, oxidation is most likely not sufficiently advanced to create the negative surface charge observed in aged biochars (MAJOR et al., 2009).

Analyzing physicochemical and structural properties of corn straw and poplar leaf biochars by scanning electron microscopy (SEM), Zhao et al. (2017) noted significant differences in images; they observed that biochar from corn straw had a bigger surface area compared to poplar leaf biochar. This is because woody plants contain larger contents of lignin and there is a negative correlation between surface area and lignin content.

Rain-fed agriculture in the semi-arid areas in northeastern Brazil has faced challenges regarding climate change and water interannual variability, mainly due to its short rainy season (4 months) uncertainties about its beginning month (January to March), which cause water stress to crops associated to a long dry season of 8 months. Besides, agriculture in this region also has to deal with soils of low water-holding capacity and poor organic matter accumulation, as high temperatures speed up crop residue decomposition.

Mitigation of regional climate variation effects and promotion of increases in water retention capacity in the soil, for a proper root and plant growth, are effective soil management alternatives to reduce drought issues and enhance crop yields.

Biochar properties and effects on soil vary widely with feedstock and processing conditions (BREWER et al., 2011). Cashew growers generate wood residues from pruning to be used as feedstock, which could be compared to available caatinga wood biochar.

The objective of this study was to identify the best biochar material regionally available to increase water-holding capacity in the soil, based on waterholding capacity tests and microstructural porosity evaluation.

\section{MATERIAL AND METHODS}

Two types of biochar were compared, which varied with the wood source (from Caatinga biome species and from cashew trees). The species from Caatinga biome were jurema-preta (Mimosa tenuiflora Willd. Poir.) and marmeleiro (Croton sonderianus Müll. Arg.), hereafter referred to as caatinga wood biochar.

Chemical analyses were performed in both biochar types for carbon content (SILVA et al., 2009), total contents of macro and micronutrients (CARMO et al., 2000), pH, EC (electrical 
conductivity), $1 \mathrm{~g}$ of biochar in $20 \mathrm{~mL}$ (RAJKOVICH et al., 2012).

In addition, samples of biochar (10 g) were evaluated for carbon stability by thermal degradation analysis, in a completely randomized design with five replications. These samples were submitted to controlled heating in a muffle furnace at 100, 200, 300,400 , and $500{ }^{\circ} \mathrm{C}$. Initially, the heating was controlled at a rate of $20{ }^{\circ} \mathrm{C}$ per minute until reaching the desired temperature. Then, the samples were heated for two hours. Prior to oven drying at $60^{\circ} \mathrm{C}$, the samples were weighed on an analytical scale and placed in porcelain crucibles. After heating, the samples were placed in a desiccator until cooling. Then, organic carbon contents were determined (YEOMANS; BREMNER, 1988), and then regressions were adjusted to mean values of organic carbon contents as a function of temperature using SigmaPlot 10.0® software.

Before evaluating water retention, both biochar materials were wetted to avoid the formation of dust during crushing in forage grinding machine. Afterward, samples were brought to the laboratory and separated using sieves of $16 \mathrm{~mm}, 8 \mathrm{~mm}, 4 \mathrm{~mm}, 2$ $\mathrm{mm}, 1 \mathrm{~mm}, 0.5 \mathrm{~mm}, 0.25 \mathrm{~mm}, 0.12 \mathrm{~mm}$, and $<0.12$ $\mathrm{mm}$ mesh. Only samples with particle sizes higher than $2 \mathrm{~mm}$ were used, once smaller particles have powder characteristics. Biochars were saturated for $24 \mathrm{~h}$ by submerging samples in tubs filled with water. Each biochar particle size was distributed in a specific pot (18 $\mathrm{cm}$ height $\mathrm{x} 22 \mathrm{~cm}$ diameter), placed in a greenhouse and submitted to environmental humidity and temperature conditions, totalizing four pots for each particle size $(2 \mathrm{~mm}, 4 \mathrm{~mm}, 8 \mathrm{~mm}, 16$ $\mathrm{mm}$ and so on). Two samples from each pot were collected and weighted using a precision scale, before being dried in an oven at $105^{\circ} \mathrm{C}$ for $24 \mathrm{~h}$ and cooled in a desiccator to be weighed later. The weight difference between wet and dried materials was considered as water retained in biochar structure. Water-holding capacity was estimated as a ratio of water and biochar weights $(\theta)$. Also, biochars with $2 \mathrm{~mm}$ and $4 \mathrm{~mm}$ particle sizes were submitted to Haines Funnel system at $10 \mathrm{kPa}$ tension.

Transversal sections of both biochars were prepared to be observed under a VEGA TESCAN scanning electron microscope (SEM) to identify macropores (between 100 and $\sim 200 \mu \mathrm{m}$ ) and micropores (below $2 \mu \mathrm{m}$ ), as suggested in Downie, Crosky and Munroe (2009). Microscope accelerating voltage was $10 \mathrm{kV}$ and a working distance of $27 \mathrm{~mm}$.

\section{RESULTS AND DISCUSSION}

According to Table 1, except for zinc (Zn) and sulfur (S), the contents of all macro and micronutrients varied between both biochars. For Amonette and Joseph (2009), mineral content of biochars vary with feedstock and process conditions, so significant differences are already expected. The same authors also reported that nitrogen $(\mathrm{N})$ is more abundant in biochars derived from manures than that in lignocellulosic biochars. Electric conductivity (EC) also differs among materials, but less than $1 \mathrm{dS}$ $\mathrm{m}^{-1}$. Although most of the wood biochars have a $\mathrm{pH}$ below 7 (JOSEPH; WILLIGEN, 2009), the values found here were above 7, being of 7.26 and 7.92 for cashew and caatinga wood biochar, respectively.

Organic carbon variation in wood biochars can be attributed to differences in ash content, which is an effect of complete combustion to $\mathrm{CO}_{2}$ (KRULL et al., 2009). Therefore, the differences found in organic carbon contents (Table 1) are due to combustion conditions, as both biochars have wood as feedstock. Biochar from cashew tree wood might have been submitted to a more complete combustion since fewer carbon contents remained in its structure. According to Joseph and Willigen (2009), carbon contents lower than $60 \%$ is considered low, between $60 \%$ to $80 \%$ as medium, and above $80 \%$ as high.

Table 1. Macro and micronutrients, $\mathrm{pH}$, and electrical conductivity (EC) in each biochar.

\begin{tabular}{lccccccccccccc}
\hline & \multicolumn{4}{c}{ Macronutrients $\left(\mathrm{g} \mathrm{kg}^{-1}\right)$} & \multicolumn{4}{c}{ Micronutrients $\left(\mathrm{mg} \mathrm{kg}^{-1}\right)$} & \multicolumn{1}{c}{$(\%)$} & $\mathrm{dS} \mathrm{m}^{-1}$ \\
\hline & $\mathrm{N}$ & $\mathrm{P}$ & $\mathrm{Mg}$ & $\mathrm{Na}$ & $\mathrm{S}$ & $\mathrm{K}$ & $\mathrm{Cu}$ & $\mathrm{Fe}$ & $\mathrm{Zn}$ & $\mathrm{Mn}$ & $\mathrm{OC}^{1}$ & $\mathrm{pH}$ & $\mathrm{EC}$ \\
Cashew & 2.86 & 1.10 & 3.16 & 1.61 & 1.58 & 5.57 & 3.40 & 369.20 & 23.40 & 92.10 & 23.02 & 7.26 & 0.22 \\
Caatinga & 5.14 & 0.20 & 7.67 & 0.77 & 1.11 & 4.14 & 5.20 & 165.50 & 23.30 & 62.90 & 48.98 & 7.92 & 0.73 \\
\hline
\end{tabular}

${ }^{1}$ organic carbono.

The C:N ratios of biochar products are reported to be similar to their corresponding feedstock material. An important way for stabilizing $\mathrm{C}$ in biochar-amended soils is reducing the metabolism of this element. The mechanisms influencing $\mathrm{C}$ stabilization in soil depends on organic carbon molecular organization, physical protection in the soil particles, and co-localization of $\mathrm{C}$ sources with microbial processes (HERNANDEZSORIANO et al., 2016).
Our results suggest that the organic matter in caatinga wood biochar is more stable than that in cashew biochar. This can be noted by observing the fitted curves (Table 2) showing that the thermoregulation of organic matter in caatinga biochar showed a sigmoidal pattern (Figure 1a) while that of cashew biochar presented a linear behavior (Figure 1b).

The plateaus of the S-curve are probably linked to the mechanisms that confer resistance to 
organic matter in caatinga biochar. But, in contrast, the linear fit of the data presented by cashew wood biochar is related to a lower resistance of its organic material (Figure 1b). The degree of $\mathrm{C}$ stability is reported to be indicated by the molar ratios $\mathrm{O} / \mathrm{C}$ and $\mathrm{H} / \mathrm{C}$. These ratios decrease with increasing pyrolysis temperatures. A high pyrolysis temperature leads to an even greater reduction in $\mathrm{C}$ and $\mathrm{N}$ concentrations. Greater C stability may occur due to secondary reactions in a very slow speed carbonization, which forms more recalcitrant biochars (FIGUEREDO et al, 2017).

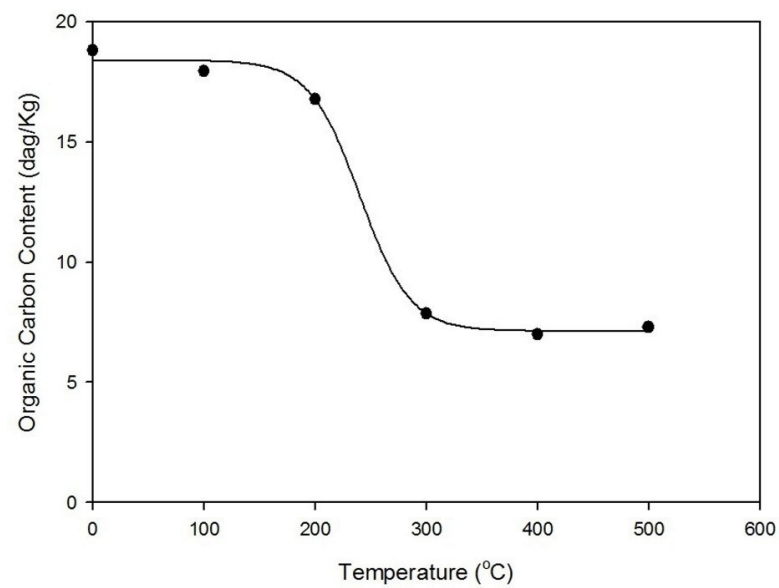

a.

Figure 1. Organic matter thermo-degradation of wood biochars (a) caatinga and (b) cashew.

Table 2. Adjusted regression equations referring to organic matter thermo-degradation for caatinga and cashew wood biochars.

\begin{tabular}{lccr}
\hline Biochar type & Adjusted regression & $\mathrm{R}^{2}$ & Probability \\
\cline { 1 - 2 } caatinga biochar. & $O C=7.1313+\frac{11.2604}{1+\mathrm{e}^{-\left(\frac{\mathrm{x}-240.1231}{-22.5360}\right)}}$ & 0.99 & 0.0037 \\
cashew biochar & $O C=13.0286-0.0134 x$ & 0.86 & 0.0052 \\
\hline
\end{tabular}

$\mathrm{OC}=$ organic carbon content $\left(\mathrm{dag} \mathrm{kg}^{-1}\right)$.

Caatinga wood biochar showed greater water -holding capacity than did cashew wood biochar in all evaluated particle sizes (Table 3). Greater contents were observed by Haines Funnel method for particle sizes of $4 \mathrm{~mm}\left(2.268 \mathrm{~g} . \mathrm{g}^{-1}\right.$ for Caatinga wood biochar) and of $2 \mathrm{~mm}\left(0.574 \mathrm{~g} . \mathrm{g}^{-1}\right.$ for cashew wood biochar). The contents found in cashew wood are close to the ones found by Liu et al. (2017) (0.52 to $0.60 \mathrm{~cm}^{3} \mathrm{~cm}^{-3}$ ) for mesquite biochar. This fact should consider environmental issues when choosing biochar feedstock and priority should be given to residues available other than native vegetation. The water-holding capacity of biochars could improve soil water retention capacity, reduce water leaching, and increase water availability in the root zone of
The conversion of organic matter to biochar by pyrolysis significantly increases $\mathrm{C}$ recalcitrance in the biomass. Biochar composition changes after a complete destruction of cellulose and lignin and appearance of aromatic structures (LEHMAN et al., 2009). The low C: $N$ ratio in cashew wood biochar (Table 1) and presence of lignified compounds (Figure 2 b.) confers this material with a lower $\mathrm{C}$ stability. However, cashew wood biochar properties could be improved by the complete destruction of cellulose and lignin, and pyrolysis temperature control. Nonetheless, increased knowledge and more research are still needed.

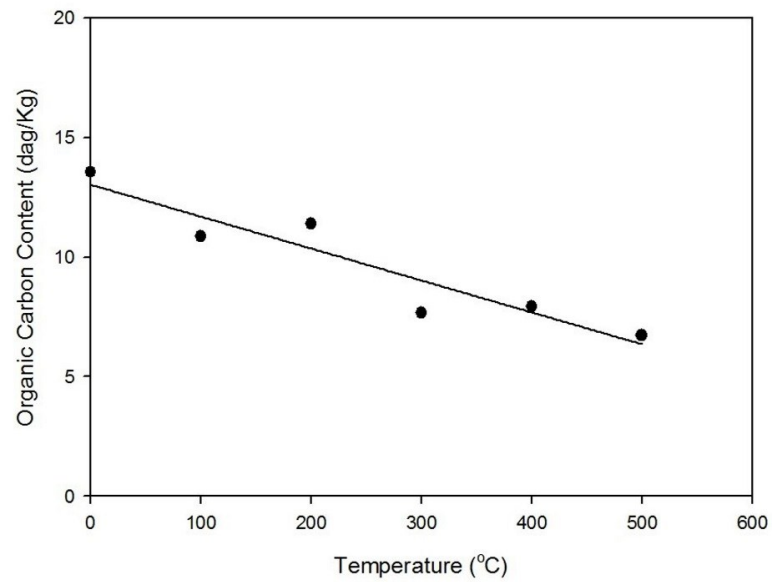

b.

crops. This fact could also improve irrigation efficiency.

In Figure 2a and 2c, a large number of macropores spread across the cashew wood biochar surface is clearly seen through the SEM images. Those cavities are related to former rays and vessels existing in the wood plant. Since these macropores allow intense water flux through their inner caliber, a less water-holding capacity is implicated in this type of biochar, according to the water-holding capacity test. Besides, the thick lignified cell walls observed in the images (Figures 2b, 2d) supports the idea that a hydrophobic effect from high cell wall lignification may contribute to the lower water-holding capacity. 
R. S. GONDIM et al.

Table 3. Water-holding capacity for different particle sizes of each studied biochar determined by weight difference and Haines Funnel (10kPa).

\begin{tabular}{|c|c|c|c|c|}
\hline \multirow[t]{2}{*}{$\begin{array}{l}\text { Particle size } \\
\quad(\mathrm{mm})\end{array}$} & \multicolumn{2}{|c|}{$\begin{array}{c}\text { Caatinga wood biochar } \\
\theta\left(\mathrm{g}^{-\mathrm{g}^{-1}}\right)\end{array}$} & \multicolumn{2}{|c|}{$\begin{array}{c}\text { Cashew wood biochar } \\
\theta\left(\mathrm{g}^{-\mathrm{g}^{-1}}\right)\end{array}$} \\
\hline & Weight & Haines Funnel & Weight & Haines Funnel \\
\hline 16 & 0.609 & & 0.281 & \\
\hline 8 & 1.262 & & 0.278 & \\
\hline 4 & 1.223 & 2.268 & 0.423 & 0.530 \\
\hline 2 & 2.638 & 1.893 & 0.602 & 0.574 \\
\hline
\end{tabular}

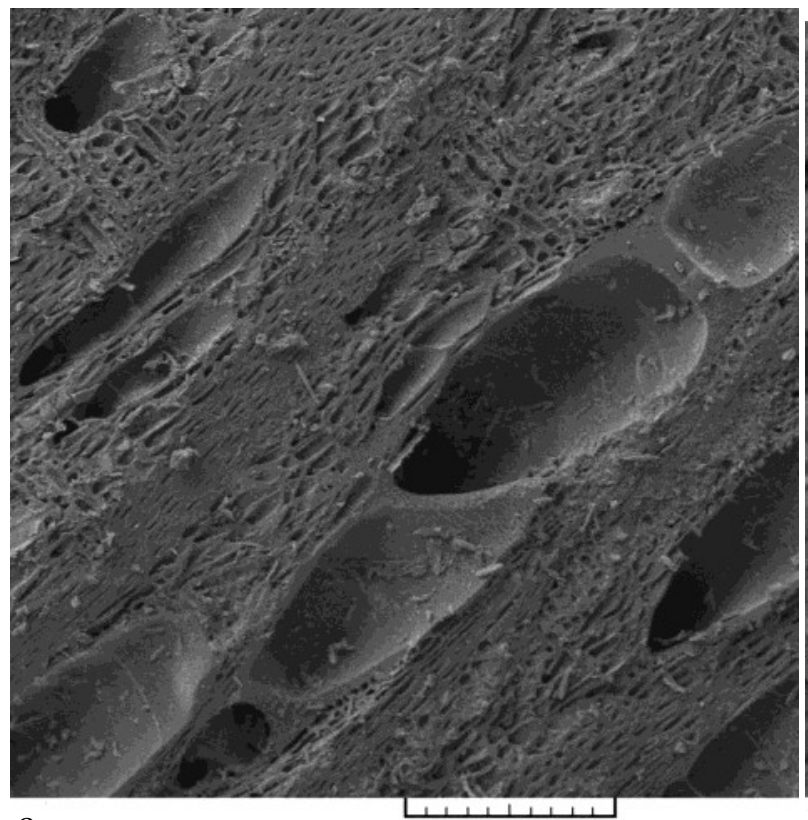

a.
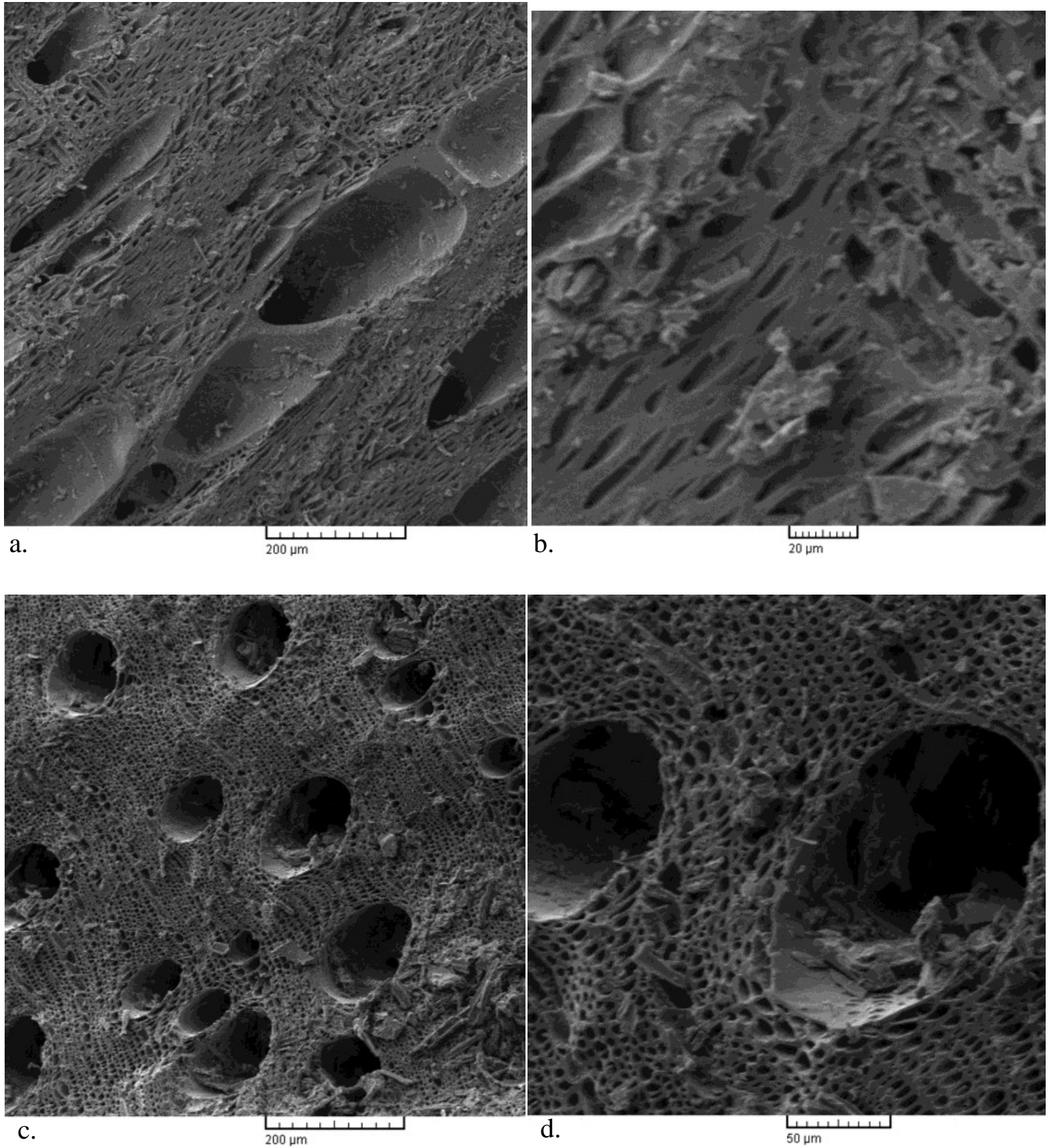

Figure 2. Scanning electron microscope images of transversal sections of cashew wood biochar: (a) longitudinal section with macropore cavities ( $\sim 200 \mu \mathrm{m}$ of size), corresponding to wood parenchyma; (b) parenchyma cells showing thick lignified cell walls; (c) macropores ( $\sim 100 \mu \mathrm{m}$ of size) with cavities originating from a vessel-rich xylem tissue; (d) vessels that increase porosity in cashew wood biochar. Thick lignification is also observed. 
According to Liu et al. (2017), biochar intrapores can increase water storage in sand-biochar mixtures with water potentials below $-16.5 \mathrm{kPa}$ and the abundance of macropores decreases its waterholding capacity; however, it could play an important role in soil microbiota. If intraporosity increases plant available water, biochar with a high intra-porosity is supposed to be most useful. The effectiveness of biochar in improving soil water retention will be reduced if biochars are hydrophobic; however, biochar hydrophobicity is usually eliminated by brief environmental exposure.

On the other hand, caatinga wood biochar images (Figure 3) showed thinner and less lignified cell walls as well as less evidence of macropores (Figure 3a). Also, fewer vessels and the preponderance of pores with sizes lower than 100 $\mu \mathrm{m}$ (Figure $3 \mathrm{~b}, \mathrm{c}$ ) confer to caatinga wood biochar greater meso- and microporosity and, consequently, a higher water-holding capacity. Thus, the preponderance of micropores explains the greater water holding capacity of this material.
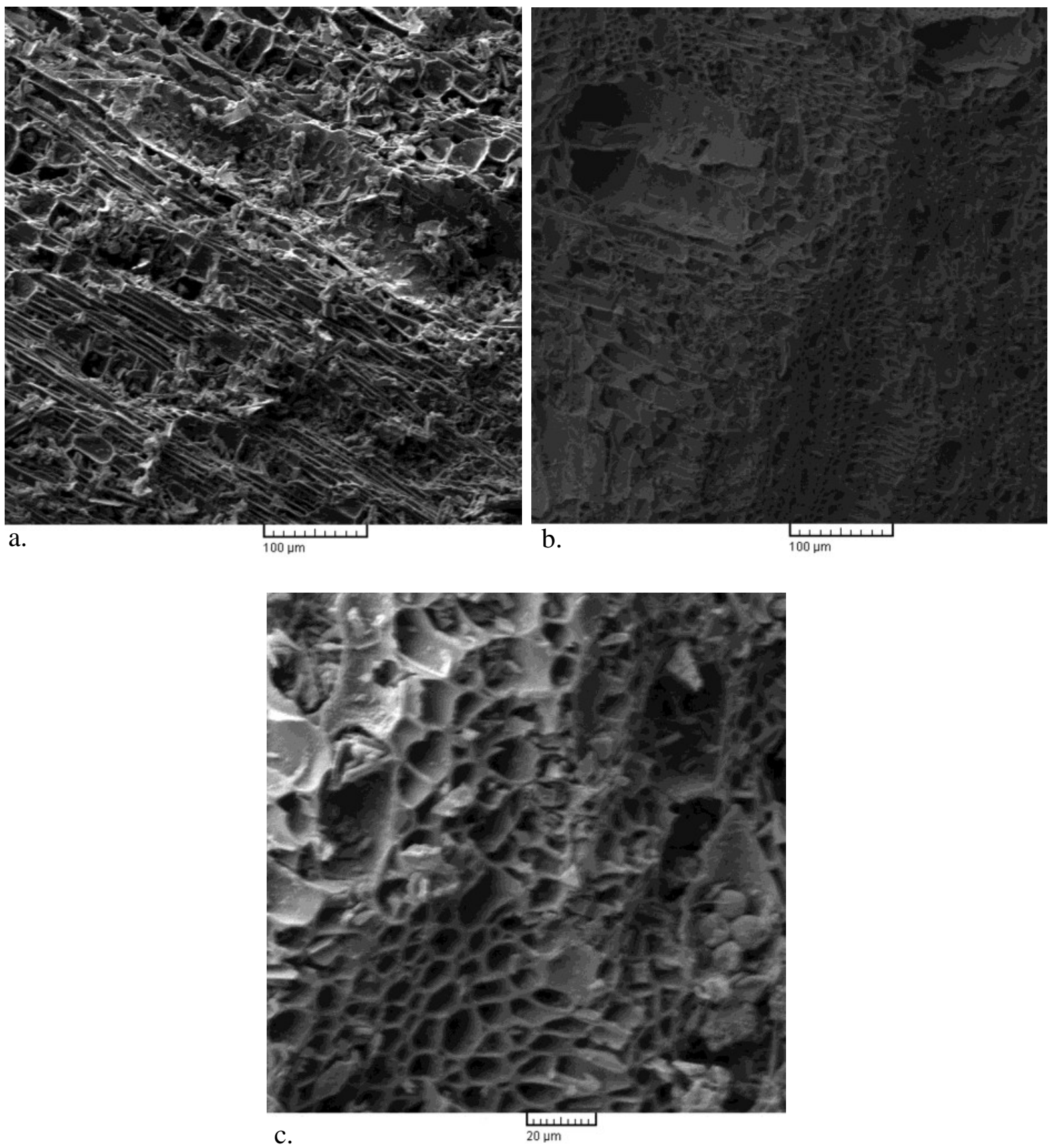

Figure 3. Scanning electron microscope images of caatinga wood biochar showing (a) thinner and less lignified cell walls with a smaller radius and fewer layers; (b) cambium system detailing with fewer vessels and size lower than $100 \mu \mathrm{m}$; (c) parenchyma tissue with lots of cell spaces and fewer vessels building higher meso- and microporosity. 


\section{CONCLUSION}

The fewer amounts of macropores and larger number of micropores (smaller radius) may be related to the higher water-holding capacity of caatinga wood biochar, while the thick lignified cell walls of cashew wood biochar support the idea of a hydrophobic effect contributing to a lower waterholding capacity, in addition to macroporosity effect. Particle size also interferes with water-holding capacity, and particles with 2 and $4 \mathrm{~mm}$ demonstrated higher levels of this property for both types of biochars.

As an important mechanism to the biocharamended soil, carbon stability appeared to be greater for caatinga wood biochar; however, cashew wood biochar properties can be improved by a complete destruction of cellulose and lignin, with pyrolysis temperature control. More research is needed.

Despite the greater water-holding capacity of caatinga wood biochar, cashew wood biochar should be chosen for environmental reasons. Crop residue biochar instead of native woody tree species should be used primarily. Besides, cashew growers have feedstock easily available.

\section{ACKNOWLEDGMENTS}

The authors would like to thank Brazilian Corporation for Agriculture Research (EMBRAPA) and National Council for Scientific and Technological Development (CNPq).

\section{REFERENCES}

AMONETTE, J. E.; JOSEPH S. Characteristics of biochar: microchemical properties In: LEHMANN J.; JOSEPH S. (Eds.). Biochar for Environmental Management. Londres: Earthscan, 2009. v. 1, cap. 3, p. 33-52.

BREWER C. E. et al. Criteria to select biochars for field studies based on biochar chemical properties. Bioenergy Research, Madison, v. 4, n. 4, p. 312$323,2011$.

CARMO, C. A. F. S. et al. Métodos de análise de tecidos vegetais utilizados na Embrapa Solos. 1. ed. Rio de Janeiro: Embrapa Solos, 2000. 41p. (Circular técnica, 6).

CHA, J.S. et al. Production and utilization of biochar: A review. Journal of Industrial and Engineering Chemistry, Seul, v.40, n.1, p.1-15, 2016.

DOWNIE, A.; CROSKY A.; MUNROE P. Physical properties of biochar In: LEHMANN, J.; JOSEPH, S. (Eds.). Biochar for Environmental Management. Londres: Earthscan, 2009. v. 1, cap. 2, p. 13-31.

FIGUEREDO, N.A. et al. Characterization of biochars from different sources and evaluation of release of nutrients and contaminant. Revista Ciência Agronômica, Fortaleza, v. 48, n. 3, p.395403, 2017.

GLASER B.; LEHMANN J.; ZECH, W. Ameliorating physical and chemical properties of highly weathered soils in the tropics with charcoal a review. Biological Fertility of Soils, Florença, v. 35, n. 4, p. 219-230, 2002.

HERNANDEZ-SORIANO, M.C. et al. Biochar affects carbon composition and stability in soil: a combined spectroscopy-microscopy study. Scientific Reports, Irvine, v. 6, n. 25. 127, p. 1-13, 2016.

JOSEPH, S.; WILLIGEN, P. Developing a biochar classification and test methods In: LEHMANN, J.; JOSEPH, S. (Eds.). Biochar for Environmental Management. Londres: Earthscan, 2009. v. 1, cap. 7, p. 107-126.

KARHU, K. et al. Biochar addition to agricultural soil increased $\mathrm{CH}_{4}$ uptake and water-holding capacity - Results from a short-term pilot field study Agriculture, Ecosystems \& Environment, Beijing, v. 140, n. 1, p. 309-313, 2011.

KAMMANN, C.I. et al. Influence of biochar on drought tolerance of Chenopodium quinoa Willd and on soil-plant relations. Plant and Soil, Crawley, v. 345, n. 1, p. 195-210, 2011.

KRULL, E. S. et al. Characteristics of biochar: organo-chemical properties In: LEHMANN, J.; JOSEPH, S. (Eds.). Biochar for Environmental Management. Londres: Earthscan, 2009. v. 1, cap. 4 , p. 53-84.

LAGHARI, M. et al. Recent developments in biochar as an effective tool for agricultural soil management: a review. Journal of the Science of Food and Agriculture, Hamilton, v. 96, n. 15, p. 4840-4849, 2016.

LEHMAN, J. et al. Stability of biochar in the soil In: LEHMANN, J.; JOSEPH, S. (Eds.). Biochar for Environmental Management. Londres: Earthscan, 2009. v. 1, cap. 11, p. 183-205.

LIU, Z. et al. Biochar particle size, shape, and porosity act together to influence soil water properties. Plos One, Melbourne, v. 12, n. 6, p. 1-19, 
2017.

MAJOR J. et al. Biochar effects on nutrient leaching In: LEHMANN J.; JOSEPH S. (Eds.). Biochar for Environmental Management. Londres: Earthscan, 2009. v. 1 , cap. 15 , p. 271-287.

NOVOTNY, E. H. et al. Biochar: pyrogenic carbon for agricultural use - a critical review. Revista Brasileira de Ciência do Solo, Viçosa, v. 39, n. 2, p. 321-344, 2015.

RAJKOVICH, S. et al. Corn growth and nitrogen nutrition after additions of biochars with varying properties to a temperate soil. Biology and Fertility of Soils, Florença, v. 48, n. 3, p. 271-284, 2012.

SILVA, F. C. et al. Métodos de análises químicas para avaliação da fertilidade do solo. In: SILVA F. C. (Ed.). Manual de análises químicas de solos, plantas e fertilizantes: análises laboratoriais. 2. ed. Brasília, DF: Embrapa Informática Agropecuária, 2009. v. 1, cap. 1, p. 107-189.

YEOMANS, J. C.; BREMNER, J. M. A rapid and precise method for routine determination of carbon in soil. Communication in Soil Science and Plant Analysis, Athens, v. 19, n. 1, p. 1467-1476, 1988.

ZHAO, N. et al. Characterization and 2D structural model of corn straw and poplar leaf biochars. Environmental Science and Pollution Research, Bethesda, v. 24, n. 34., p. 1-10, 2017. 